\title{
Troglitazone Inhibits Vascular Endothelial Growth Factor-Induced Angiogenic Signaling via Suppression of Reactive Oxygen Species Production and Extracellular Signal-Regulated Kinase Phosphorylation in Endothelial Cells
}

\author{
Byung Chul Park ${ }^{1}$, Dinesh Thapa ${ }^{1}$, Jong Suk Lee ${ }^{1}$, Su-Young Park ${ }^{1}$, and Jung-Ae Kim ${ }^{1, *}$ \\ ${ }^{1}$ College of Pharmacy, Yeungnam University, Gyeongsan 712-749, Korea
}

Received November 13, 2008; Accepted April 13, 2009

\begin{abstract}
Thiazolidinediones, peroxisome proliferators-activated receptor gamma (PPAR $\gamma$ ) ligands, have been recognized as a potential therapeutic agents for the treatment of pathological neovascularization. In the present study, we examined the molecular mechanism by which troglitazone (TROG), a PPAR $\gamma$ agonist, exerts its inhibitory action in vascular endothelial growth factor (VEGF)-induced angiogenesis signaling. In an in vitro angiogenesis model using human umbilical vein endothelial cells, TROG $(20 \mu \mathrm{M})$ significantly suppressed VEGF-induced cell proliferation and invasion of the cells into the Matrigel basement membrane, which was not reversed by treatment with PPAR antagonists, GW9662 $(10 \mu \mathrm{M})$ and bisphenol A diglycidyl ether $(10 \mu \mathrm{M})$. TROG also blocked VEGF-induced reactive oxygen species (ROS) production and its downstream extracellular signal-regulated kinase (ERK) phosphorylation, and this inhibitory effect was not reversed by GW9662 $(10 \mu \mathrm{M})$. The antiangiogenic activity of TROG correlated with suppression of VEGF-induced matrix metalloproteinase (MMP)-2 and membrane type 1 (MT1)-MMP expression. In addition, the effects of TROG on VEGF-induced MMP-2 and MT1-MMP expression were comparable to those of the NADPH oxidase inhibitor diphenylene iodium $(10 \mu \mathrm{M})$ and ERK inhibitor PD98056 $(10 \mu \mathrm{M})$. Furthermore, in an in vivo angiogenesis system using a chick chorioallantoic membrane model, TROG dose-dependently inhibited VEGF-induced angiogenesis, which was similar to the inhibitory effect of $\mathrm{N}$-acetylcysteine on VEGF-induced angiogenesis. The results suggest that the inhibitory effects of TROG on VEGFinduced angiogenesis were mediated through the suppression of VEGF-induced ROS production and ERK phosphorylation.
\end{abstract}

Keywords: angiogenesis, troglitazone, matrix metalloproteinase (MMP), reactive oxygen species (ROS), extracellular signal-regulated kinase (ERK)

\section{Introduction}

Angiogenesis, the growth of new capillaries from preexisting micro-vessels, plays an important role not only in physiological process such as embryonic development and wound healing, but also in the progression of various pathological conditions such as cancers, rheumatoid arthritis, and diabetic retinopathy $(1,2)$. Vascular endothelial growth factor (VEGF) is the most

*Corresponding author. jakim@ynu.ac.kr

Published online in J-STAGE

doi: 10.1254 /jphs.08305FP well-known proangiogenic factor, and its action is primarily mediated through interaction with its receptor VEGFR2 (3). The activation of VEGFR2 is known to be associated with the activation of NADPH oxidase, which generates reactive oxygen species (ROS) and subsequent activation of the mitogen-activated protein kinase (MAPK) cascade during angiogenesis $(4-6)$.

For migration and invasion of endothelial cells into the surrounding tissue during angiogenesis, proteases such as matrix metalloproteinases (MMPs) are necessary to degrade tissue barriers. MMP-2 and MMP-9 are the major MMP species for degrading type IV collagen, a major component of the basement membrane (7). They 
are abundantly expressed in cancer cells $(8,9)$ and vasculature $(10,11)$ and play an important role in not only the migration of inflammatory cells and tumor cells into the basement membrane, but also in the sprouting of endothelial cells by VEGF (12). MMP-2 is secreted as an inactive zymogen that can be activated at the cell membrane via the membrane-type MMP (MT1-MMP) (13). ROS is an important signal required for the activation and expression of pro-MMP-2 in both cancer cells (14) and vascular cells (15).

Peroxisome proliferators-activated receptor gamma $(\operatorname{PPAR} \gamma)$, one of the PPAR members of the nuclear hormone receptor superfamily, plays an important role in obesity, diabetes, inflammation, and tumorigenesis by regulating cellular proliferation and differentiation. An increasing line of evidence has shown that PPAR $\gamma$ ligands also exert inhibitory effects on the cytokineinduced proliferation and migration of various types of cells $(16-18)$. In leukemia cells and vascular smooth muscle cells, the anti-migratory action of troglitazone (TROG), one of the PPAR $\gamma$ agonists, correlates with its regulatory effects on MMP expression $(19,20)$. However, in vascular endothelial cells, only TROG, but not pioglitazone and rosiglitazone, exerts a regulatory effect on MMP expression (21). These reports suggest that TROG, among the PPAR $\gamma$ ligands, may serve as an anti-angiogenic agent by inhibiting proliferation, migration, and MMP expression in endothelial cells. However, the detailed signaling pathway of TROG involved in the anti-angiogenic action is not yet available.

In the present study, we investigated the effects and action mechanism of TROG on the VEGF-induced angiogenesis in relation to MMP activation and expression.

\section{Materials and Methods}

\section{Materials}

The basic form of VEGF was purchased from R\&D Systems (Minneapolis, MN, USA). Endothelial growth medium (EGM)-2 bullet kit containing an endothelial cell basal medium (EBM)-2 and EGM-2 SingleQuots (hydrocortisone, hFGF, VEGF, R3-IGF-1, ascorbic acid, hEGF, heparin, gentamicin, and FBS) was purchased from Clonetics (San Diego, CA, USA). HEPES-buffered saline solution, trypsin/EDTA, and trypsin neutralizing solution (TNS) were purchased from Clonetics, Inc. (Walkersville, MD, USA). The polymer Matrigel was purchased from BD Biosciences (Bedford, MA, USA). The [4,5-dimethylthiazol-2-yl]-2,5-diphenyltetrazolium bromide (MTT), 2\% gelatin solution, $N$-acetyl-L-cysteine (NAC), TROG, diphenylene iodium (DPI), PD98059, cortisone acetate, and 2',7'-dichlorofluorescein diacetate
(DCF-DA) were purchased from Sigma (St. Louis, MO, USA).

\section{Cell culture}

Human umbilical vein endothelial cells (HUVECs) were purchased from Clonetics (San Diego, CA, USA). HUVECs were grown to $80 \%-90 \%$ confluence in EBM-2 containing hydrocortisone, hFGF, VEGF, R3IGF-1, ascorbic acid, hEGF, heparin, gentamicin, and $2 \%$ FBS equilibrated with $5 \% \mathrm{CO}_{2}$ at $37^{\circ} \mathrm{C}$. HUVECs were serially passaged and maintained in EBM-2 in cell culture flasks coated with $0.2 \%$ gelatin (Sigma). Confluent cultures of HUVECs between the third and sixth passages were washed with HEPES-buffered saline solution and harvested using trypsin/EDTA and neutralization by TNS.

\section{Cell proliferation assay}

HUVECs plated at a density of $2 \times 10^{4}$ cells/well in 48-microwell plates were incubated for $24 \mathrm{~h}$ in EBM-2 containing only $1 \%$ FBS and cotreated with VEGF $(20 \mathrm{ng} / \mathrm{ml})$ and TROG for $48 \mathrm{~h}$. After incubation, an MTT assay was carried out and the optical density was measured at $540 \mathrm{~nm}$ using a microplate reader (Versa MAX ; Molecular Devices, Sunnyvale, CA, USA).

\section{Determination of intracellular of ROS production}

Intracellular ROS generation was measured using 2',7'-dichlorofluorescein diacetate (DCF-DA), a fluorescent dye (22). Confluent cells were pretreated with inhibitors and then treated with $20 \mathrm{ng} / \mathrm{ml}$ VEGF. After incubation for $5 \mathrm{~min}$, the cells were loaded with $10 \mu \mathrm{M}$ DCF-DA for $5 \mathrm{~min}$ at $37^{\circ} \mathrm{C}$ and imaged by an inverted fluorescence microscopy (TE2000-U; Nikon, Tokyo).

\section{Tube formation assay}

The tube formation assays were performed on 48-well plates coated with $100 \mu$ l of Matrigel basement membrane matrix per well and polymerized at $37^{\circ} \mathrm{C}$ for $30 \mathrm{~min}$. HUVECs were suspended in $2 \%$ FBS and another supplement containing EBM-2 medium. The cells were plated on Matrigel at a density of $5 \times 10^{4}$ cells per well, and test compound was added to the culture medium. After $14 \mathrm{~h}$, four fields were randomly selected from each culture and photographed with a CCD camera (TE2000-U, Nikon).

\section{In vitro invasion assay}

An in vitro invasion assay was performed using a 24-transwell unit (8- $\mu \mathrm{m}$ pore size) with polycarbonate filters (Corning, Cambridge, MA, USA) by the previously described method (23). The upper and lower sides of the transwell filter were coated with $40 \mu \mathrm{l}$ of 
Matrigel $(0.5 \mathrm{mg} / \mathrm{ml})$ (BD Biosciences) and type I collagen $(0.5 \mathrm{mg} / \mathrm{ml})$, respectively. The lower compartment was filled with EBM-2 containing EGM-2 SingleQuots and 1\% FBS. The cells were placed in the upper part of the transwell plate and incubated with VEGF $(20 \mathrm{ng} / \mathrm{ml})$ for $24 \mathrm{~h}$ at $37^{\circ} \mathrm{C}$. TROG was coadministered with VEGF, and pretreatment with the other inhibitors was performed $30 \mathrm{~min}$ before VEGF treatment. The cells that invaded the lower surface of the membrane were fixed with methanol and stained with hematoxylin and eosin. We determined invasive phenotypes by counting the cells that migrated to the lower side of the filter using $\times 200$ magnification. Three fields were counted for each filter.

\section{Zymography}

The enzymatic activities of MMP-2 and MMP-9 were assayed by gelatin zymography (24) in the absence of serum. Supernatants from TROG with or without VEGF cultures were electrophoresed using 10\% sodium dodecyl sulfate polyacrylamide gel electrophoresis (SDSPAGE) containing gelatin. The gel was washed twice with washing buffer [50 mM Tris- $\mathrm{HCl}(\mathrm{pH} 7.5), 100 \mathrm{mM}$ $\mathrm{NaCl}, 2.5 \%$ Triton $\mathrm{X}-100$ ], followed by a brief rinsing in washing buffer without Triton X-100, and then incubated with incubation buffer $[50 \mathrm{mM}$ Tris- $\mathrm{HCl}$ (pH 7.5), $150 \mathrm{mM} \mathrm{NaCl}, 10 \mathrm{mM} \mathrm{CaCl}_{2}, 0.02 \% \mathrm{NaN}_{3}$ ) at $37^{\circ} \mathrm{C}$. After incubation, the gel was stained with $0.25 \%$ Coomassie Brilliant Blue R250 (Sigma) and then destained. A clear zone of gelatin digestion represented MMP activity.

\section{MMP-2 ELISA}

An enzyme-linked immunosorbent assay (ELISA) kit (Oncogene Research Products, Boston, MA, USA) was used to measure the extracellular protein levels of MMP-2 according to the manufacturer's protocol. Three independent experiments in duplicate were performed.

\section{Quantitative real-time polymerase chain reaction (PCR)}

Cells were collected and total RNA was extracted with a spin column using the RNeasy mini kit (Qiagen, Hilden, Germany) according to the manufacturer's instructions. Isolated mRNA was reverse-transcribed by using the Reverse Transcription kit (Qiagen). The gene expression levels were analyzed by a Quantitative RealTime PCR system (Rotor-Gene 6000; Corbett, San Francisco, CA, USA). Real-time PCR was performed with the SYBR Green PCR kit (Qiagen). The following primers were used for PCR analysis: MMP-2 stock primer (Qiagen Cat. No. QT00088396) and MT1-MMP stock primer (Qiagen Cat. No. QT00001533). The reaction mixture consisted of $2 \mu \mathrm{l}$ of cDNA template,
$10 \mu \mathrm{l}$ of SYBR Green PCR master mix, $5 \mathrm{pM}$ of primers, and RNase free water in a total volume of $20 \mu \mathrm{l}$. The cDNA was denatured at $95^{\circ} \mathrm{C}$ for $15 \mathrm{~min}$ followed by 55 cycles of PCR $\left(95^{\circ} \mathrm{C}\right.$ for $5 \mathrm{~s}, 55^{\circ} \mathrm{C}$ for $10 \mathrm{~s}, 72^{\circ} \mathrm{C}$ for $20 \mathrm{~s}$ ). The mRNA levels of all genes were normalized using glyceraldehyde-3-phosphate dehydrogenase (GAPDH) stock primer (Qiagen Cat. No. QT00079247) as an internal control.

\section{Western blotting}

After HUVECs were treated with the test drugs, the cells were immediately washed with ice-cold PBS and scraped with a rubber policeman in ice-cold homogenization buffer [20 mM HEPES (pH 7.4), $1 \mathrm{mM}$ EDTA, $20 \mu \mathrm{g} / \mathrm{ml}$ leupeptin, $10 \mu \mathrm{g} / \mathrm{ml}$ aprotinin, $2 \mu \mathrm{g}$ $/ \mathrm{ml}$ pepstain, $1 \mathrm{mM}$ PMSF, $1 \mathrm{mM}$ DTT). Total proteins were extracted using a lysis buffer [20 mM HEPES (pH 7.5), $20 \mathrm{mM} \mathrm{KCl}, 1.5 \mathrm{mM} \mathrm{MgCl}_{2}, 1 \mathrm{mM}$ EDTA, $1 \mathrm{mM}$ EGTA, $1 \mathrm{mM}$ DTT, $1 \mathrm{mM}$ PMSF, $1 \mathrm{mM} \mathrm{Na}_{3} \mathrm{VO}_{3}$, and $1 \mathrm{X}$ Protease Inhibitor Cocktail], and samples (each containing $30 \mu \mathrm{g}$ of protein) were separated by SDSPAGE. The resolved proteins were electrophoretically transferred onto a nitrocellulose membrane from the gel. The nitrocellulose blots were blocked for $1 \mathrm{~h}$ at $37^{\circ} \mathrm{C}$ using $5 \%$ skim milk in TBS-T buffer (TBS buffer containing $0.1 \%$ Tween-20). After 3 washes with TBS$\mathrm{T}$, the blots were incubated with primary antibodies, p-ERK (Santa Cruz Biotechnology Inc., Santa Cruz, CA, USA) and ERK (Cell Signaling, Beverly, MA, USA) in $5 \%$ skim milk in TBS overnight at $4^{\circ} \mathrm{C}$ on a shaker. For the detection of phosphorylated proteins, bovine serum albumin was used to block nonspecific binding. After 3 washes with TBS-T, the blots were incubated with horseradish peroxidase-conjugated antirabbit IgG secondary antibody (Santa Cruz Biotechno$\operatorname{logy}$ ) for $1 \mathrm{~h}$ at room temperature. Then the blots were washed again and visualized with enhanced chemiluminescence (ECL) detection. The abundance of each protein was detected and normalized to that of actin. This experiment was repeated three times.

\section{Chick chorioallantoic membrane (CAM) assay}

The 10-day-old embryos were purchased from Baek-ja farm (Cheongsong, Korea) and were incubated at $37^{\circ} \mathrm{C}$ with $55 \%$ relative humidity. A small hole was punctured in the shell concealing the air sac using a hypodermic needle. A second hole was punctured in the shell on the broadside of the egg directly over the avascular portion of the embryonic membrane, as observed during candling. A false air sac was created beneath the second hole by the application of negative pressure to the first hole, which caused the CAM to separate from the shell. A window, approximately $1.0 \mathrm{~cm}^{2}$, was cut in the shell 

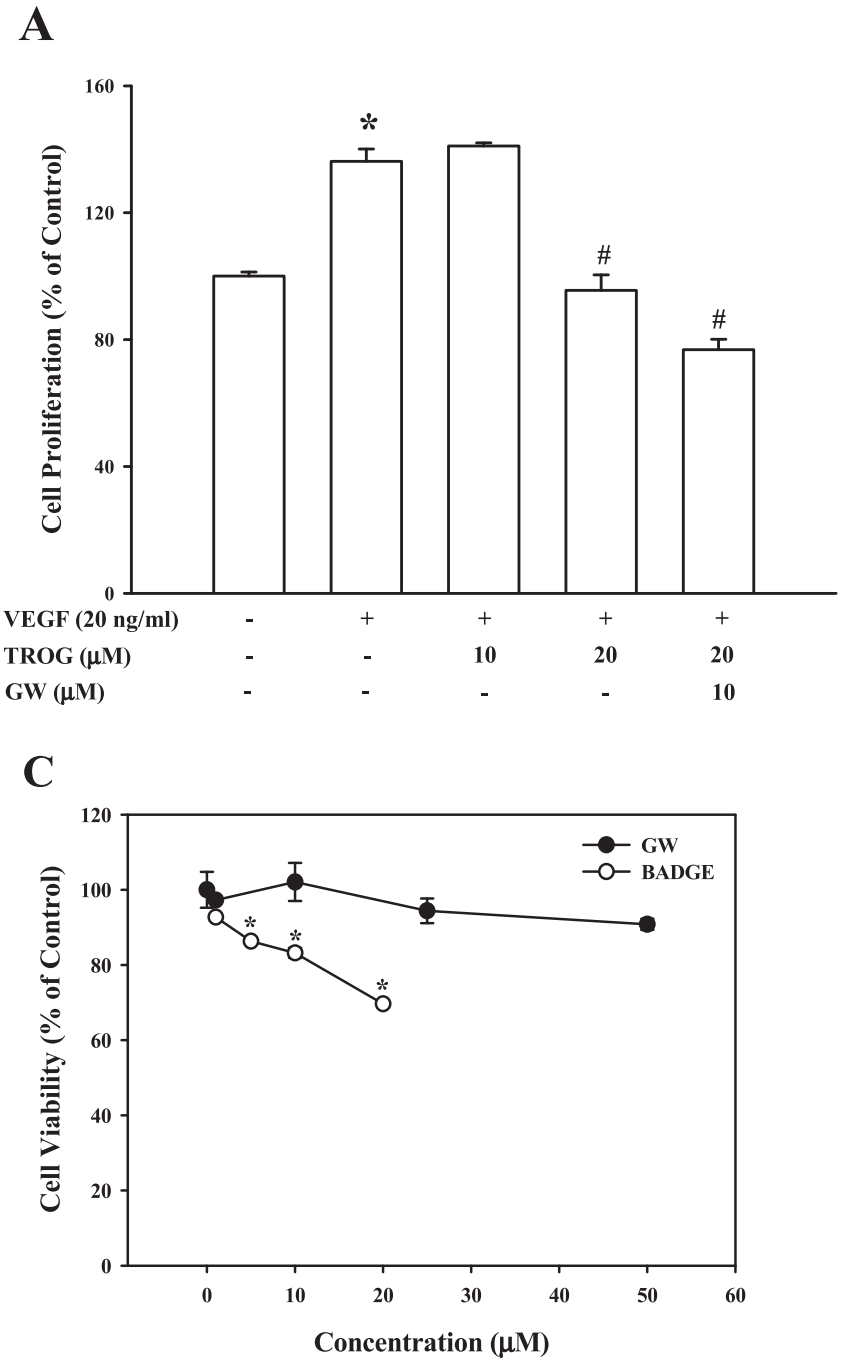

over the dropped CAM with the use of a small crafts grinding wheel (Dremel, Racine, WI, USA). Sterile filter disks (Whatman No.1 filter paper; Maidstone, UK) were soaked in $3 \mathrm{mg} / \mathrm{ml}$ cortisone acetate in a solution of $90 \%$ ethanol and water and subsequently air-dried under sterile conditions. VEGF was used to grow vessels on the CAMs of 10-day-old chick embryos. Sterile filter disks, absorbed with VEGF $(20 \mathrm{ng} / \mathrm{ml})$ dissolved in PBS containing $0.1 \% \mathrm{BSA}$, were placed on the growing CAMs. Then, test compounds or vehicle was added directly to the CAMs topically. CAM tissue directly beneath the VEGF-saturated filter disks was resected from embryos treated $72 \mathrm{~h}$ previously with compound or vehicle. CAM disks were harvested for light microscopy (Leica, Germany). The number of vessel branch points contained in a circular region equal to the area of filter disk was counted for each section.
B

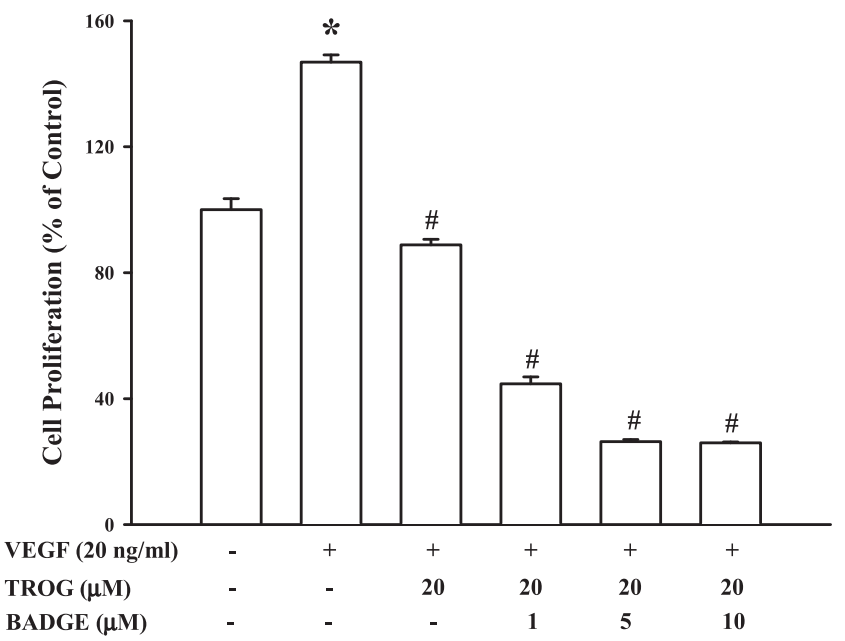

Fig. 1. Effects of TROG on VEGF-induced HUVEC proliferation. A and B: The serum-starved HUVECs $\left(1 \times 10^{4}\right.$ cells/well $)$ were stimulated with $20 \mathrm{ng} / \mathrm{ml}$ of VEGF in the presence or absence of TROG for $48 \mathrm{~h}$, and then the number of viable cells was measured using the MTT method. The cells were pretreated with GW9662 for $30 \mathrm{~min}$ prior to co-treatment with VEGF and TROG. C: HUVECs were treated for $48 \mathrm{~h}$ with or without each concentration of GW9662 or BADGE, and cell viability was measured using the MTT assay. Data are each the mean \pm S.E.M. from three independent experiments. ${ }^{*} P<0.05$, compared to the vehicle-treated control; ${ }^{\#} P<0.05$, compared to the VEGF-treated group.

\section{Statistics}

The data are each expressed as the mean \pm S.E.M. and were analyzed by one-way analysis of variance (ANOVA) and the Student-Newman-Keul's test for individual comparisons. $P$ values of $<0.05$ were considered statistically significant.

\section{Results}

TROG inhibits VEGF-induced HUVEC proliferation via suppression of ROS and ERK phosphorylation

Since the angiogenic process includes the proliferation, migration, and tube formation of endothelial cells (ECs), we examined the effects of TROG on each of the angiogenic processes in vitro using HUVECs. To examine the effect of TROG on the VEGF-induced endothelial cell proliferation, an MTT assay was performed. Treatment of the serum-starved HUVECs with VEGF $(20 \mathrm{ng} / \mathrm{ml})$ for $48 \mathrm{~h}$ increased proliferation of 

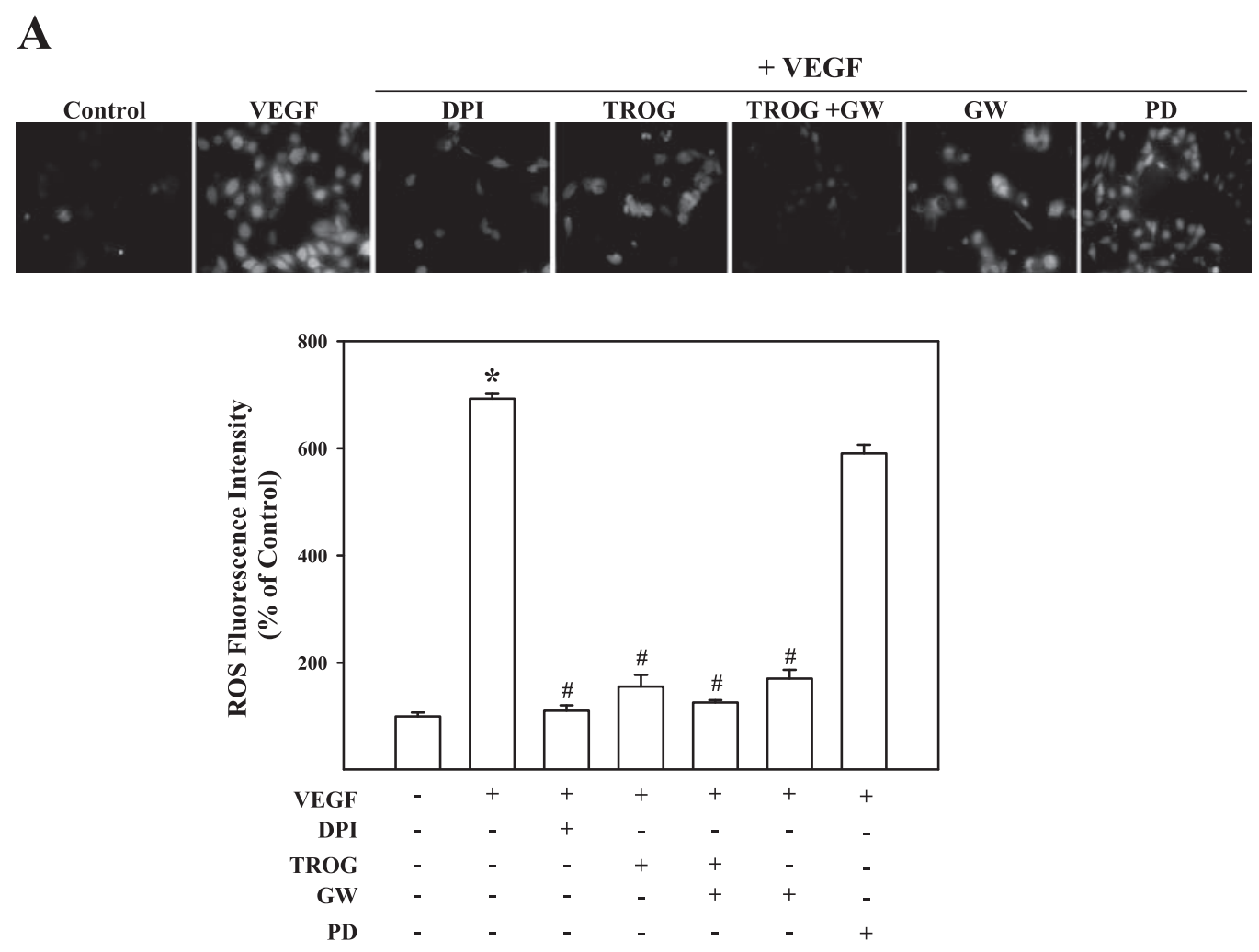

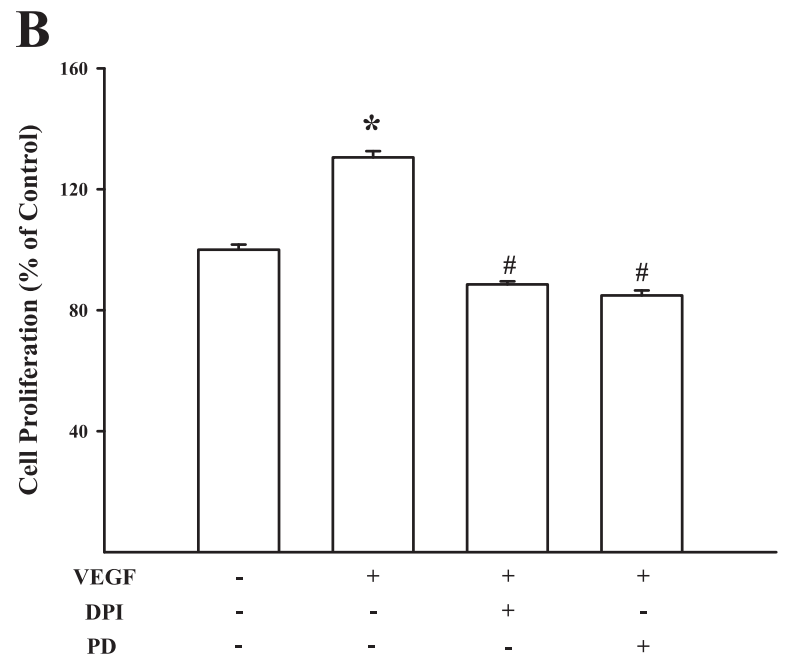

the cells, and this VEGF-induced proliferation was significantly suppressed by TROG $(20 \mu \mathrm{M})$ (Fig. 1: A and $\mathrm{B})$. In order to determine whether the effect of TROG was PPAR $\gamma$-dependent, the cells were treated with GW9662 $(10 \mu \mathrm{M})$ and bisphenol A diglycidyl ether (BADGE) $(1,5,10 \mu \mathrm{M})$, PPAR antagonists, in combination with TROG. In fact, PPAR antagonists failed to reverse the anti-proliferative effect of TROG (Fig. 1: A and B). Rather, the addition of GW9662 and BADGE enhanced the inhibitory effects of TROG. Of particular note was that the treatment of BADGE alone
Fig. 2. VEGF-induced ROS production in HUVECs was inhibited by TROG and DPI, but not by PD98059. A: Serum-starved HUVECs were stimulated with VEGF $(20 \mathrm{ng} / \mathrm{ml})$ for $5 \mathrm{~min}$ in the presence or absence of drugs and then incubated with DCF-DA $(5 \mu \mathrm{M})$ for an additional $5 \mathrm{~min}$. In the case of DPI and PD98059, the drug was co-administered with VEGF; and for GW9662 treatment, cells were pretreated with the drug for $30 \mathrm{~min}$ prior to VEGF treatment. The cellular ROS level was captured under a fluorescence microscope (TE2000-U; Nikon, Tokyo) at $\times 200$ magnification, and the images were imported and analyzed by using the Image-Inside program. The bar graphs represent the relative intensity of fluorescence. B: The cell proliferation was measured as described in Fig. 1A. Data are each the mean \pm S.E.M. from three independent experiments. ${ }^{*} P<0.05$, compared to the vehicle-treated control; ${ }^{\#} P<0.05$, compared to the VEGF-treated group.

significantly reduced the cell viability (Fig. 1C).

Since the VEGF-induced proliferation is mediated through the generation of ROS by NADPH oxidase (5), which in turn, activates ERK, we also tested whether the anti-proliferative effect of TROG was due to the suppression of ROS and ERK (25). TROG $(20 \mu \mathrm{M})$ significantly inhibited the VEGF-induced ROS generation (Fig. 2A), which was comparable to the effects of treatment with DPI $(10 \mu \mathrm{M})$, an NADPH oxidase inhibitor, on VEGF-induced ROS generation (Fig. 2A) as well as cell proliferation (Fig. 2B). Such an inhibitory 
A
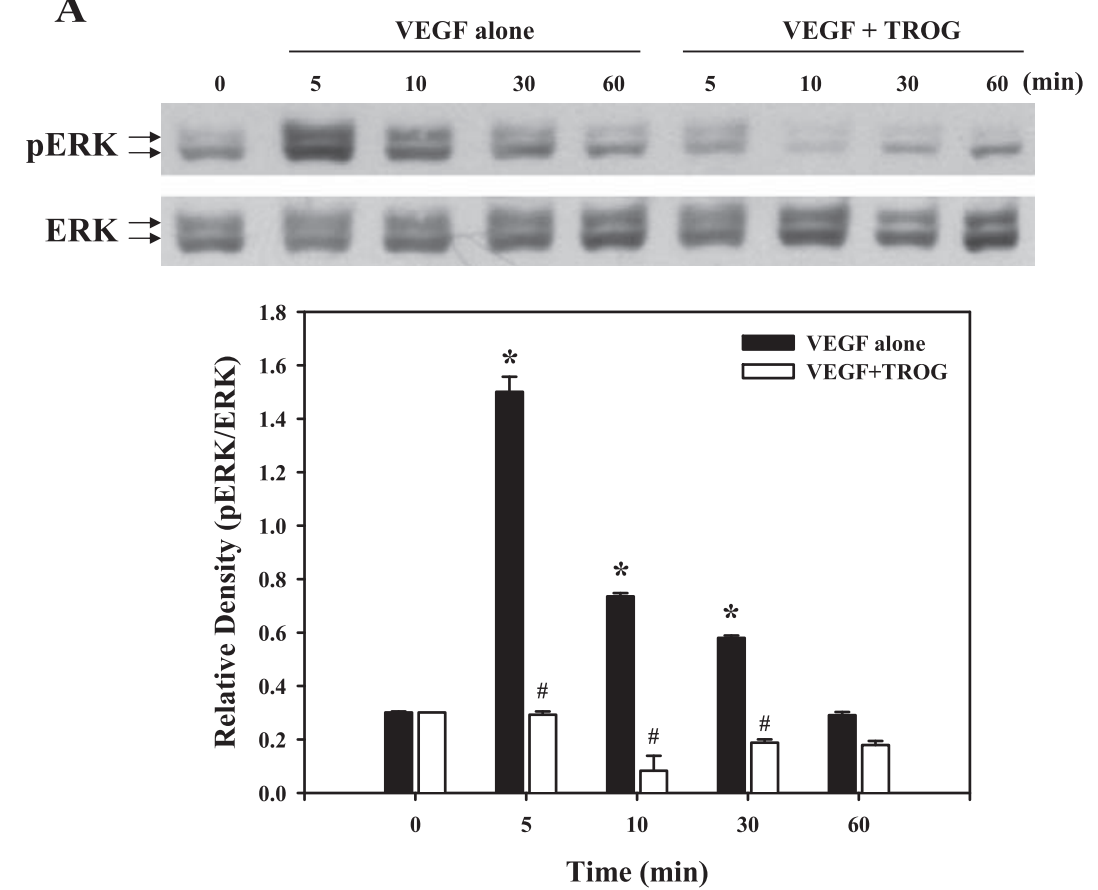

B
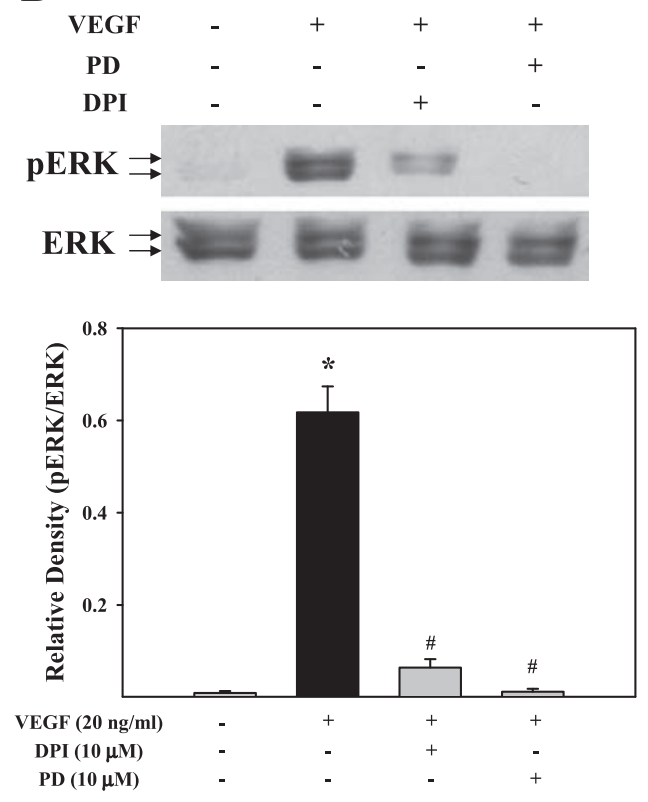

Fig. 3. TROG and DPI inhibits VEGF-induced ERK phosphorylation. A: HUVECs were treated with VEGF in the absence or presence of TROG for the indicated time. B: The cells were co-treated with VEGF and PD98059 or DPI for 5 min. Protein lysates were extracted and analyzed for the expression level of phospho-ERK and ERK by immunoblotting. In the bar graph, the relative expression of phosphorylated ERK normalized to ERK level is expressed as the mean \pm S.E.M. ${ }^{*} P<0.05$, compared to the vehicle-treated control; ${ }^{\#} P<0.05$, compared to the VEGF-treated group.

effect of TROG was not reversed by co-treatment with GW9662 $(10 \mu \mathrm{M})$. Rather, GW9662 itself suppressed the VEGF-induced ROS generation. In the case of the treatment with PD98059 $(10 \mu \mathrm{M})$, an ERK1/2 inhibitor, it did not suppress the VEGF-induced ROS, but significantly suppressed the VEGF-induced endothelial cell proliferation (Fig. 2B). Moreover, as shown in Fig. 3A, treatment of HUVECs with VEGF significantly induced phosphorylation of ERK, most strongly at $5 \mathrm{~min}$ and then decreased shortly thereafter. This VEGFinduced ERK phosphorylation was suppressed by treatment with TROG $(20 \mu \mathrm{M})$. In a parallel experiment, DPI $(10 \mu \mathrm{M})$ also suppressed the VEGF-induced ERK phosphorylation in a similar manner to TROG (Fig. 3B).

\section{TROG suppresses tube formation and invasion of human} endothelial cells by VEGF

When HUVECs were placed on Matrigel in the presence of VEGF $(20 \mathrm{ng} / \mathrm{ml})$, the cells rapidly aligned with one another and formed tube-like structures within $12 \mathrm{~h}$. Treatment of the cells with TROG (10 and $20 \mu \mathrm{M})$ concentration-dependently prevented the VEGF-stimulated tube formation of HUVECs (Fig. 4A). Similarly, TROG significantly suppressed VEGF-induced invasion of the cells in the Matrigel invasion assay (Fig. 4B). In addition, the effect of TROG $(20 \mu \mathrm{M})$ was comparable to those of DPI $(10 \mu \mathrm{M})$ and PD98059 $(10 \mu \mathrm{M})$. On the other hand, the inhibitory action of TROG on VEGFinduced invasion of HUVECs was not reversed by cotreatment with GW9662 $(10 \mu \mathrm{M})$. The treatment with a drug alone (TROG, GW, DPI, and PD) in the absence of VEGF did not alter the invasive behavior of the cells (Fig. 4C).

\section{TROG inhibits VEGF-induced MMP-2 and MT1-MMP expressions in HUVECs}

For the migration and invasion of endothelial cells into the surrounding tissue during angiogenesis, the cells require proteases such as MMPs to degrade tissue barriers presented by basement membranes and the interstitial matrix. We examined the effect of TROG on VEGF-induced MMP-2 and MT1-MMP level in HUVECs.

In a real-time PCR assay, treatment of the cells with TROG (10 and $20 \mu \mathrm{M})$ significantly suppressed not only the basal expression of MMP-2 and MT1-MMP but also the VEGF-induced MMP-2 (Fig. 5A) and MT1MMP (Fig. 5B) mRNA expression in a concentrationdependent manner. This inhibitory effect of TROG was stronger than the effect produced by treatment with 
A

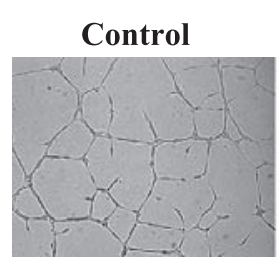

TROG $(20 \mu \mathrm{M})$

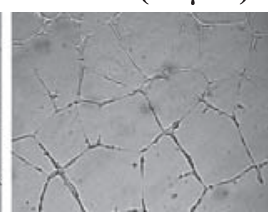

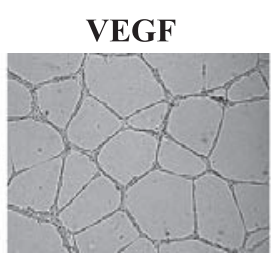

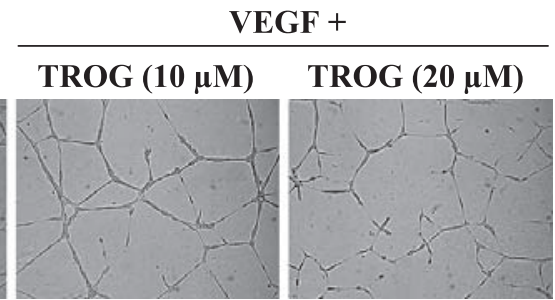

B

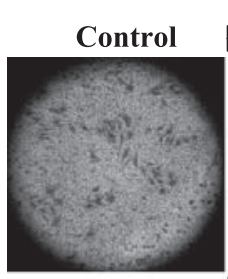

VEGF

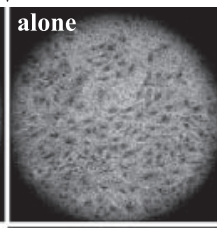

+TROG (20)+GW
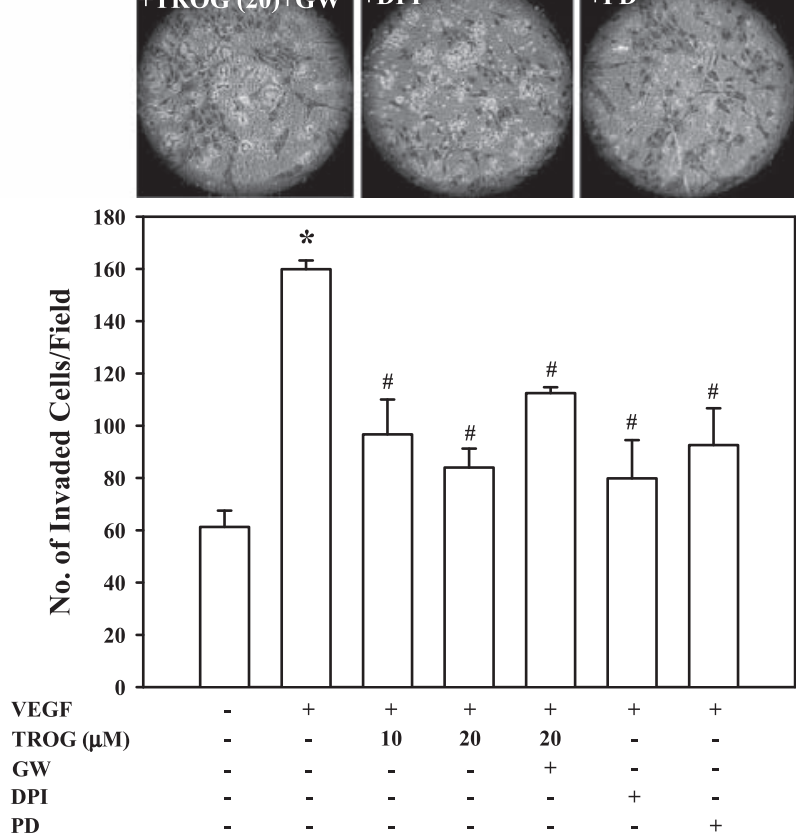

C
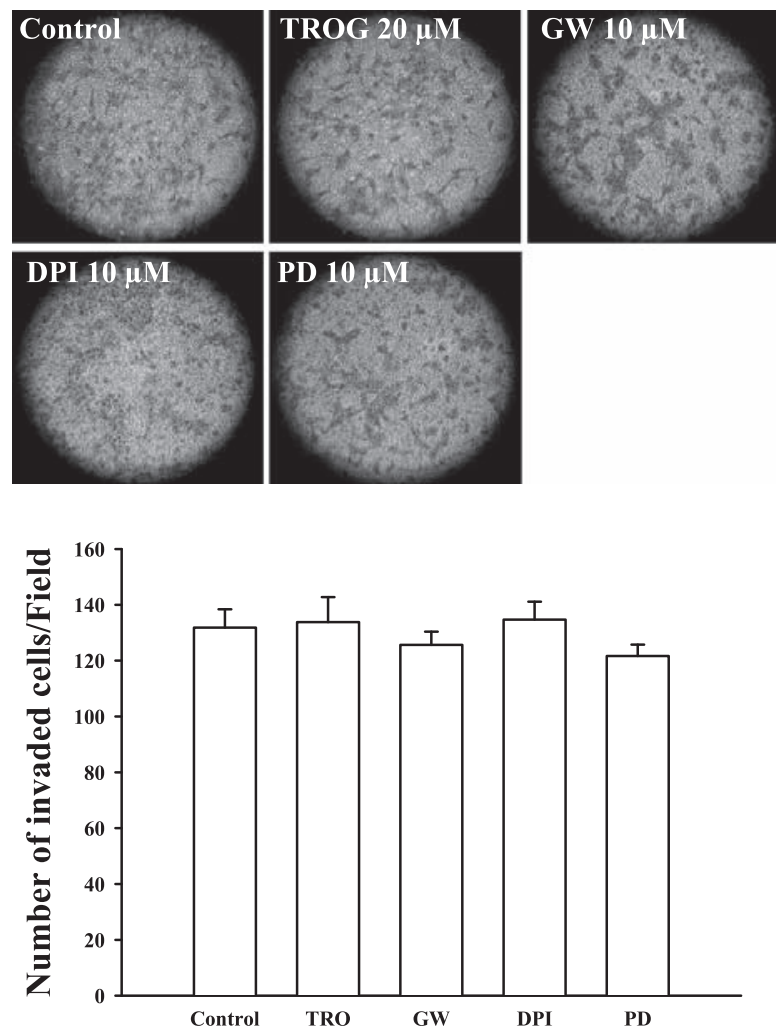

Fig. 4. Inhibitory effect of TROG on VEGF-induced tube formation and invasion of HUVECs. A: HUVECs were plated on a well coated with $40 \mu \mathrm{l}$ of Matrigel basement membrane matrix. After they were treated with VEGF and TROG for $12 \mathrm{~h}$, the cells were photographed using a digital camera attached to a phase contrast microscope at $\times 100$ magnification. B and C: The lower and upper parts of the transwell insert were coated with collagen and Matrigel, respectively. HUVECs were treated with TROG, DPI, PD98059, or GW9662 in the presence (B) or absence (C) of VEGF. After $24 \mathrm{~h}$, the cells on the bottom side of the filter were fixed, stained, and captured under a microscope. The bar graphs represent the mean number of cells invaded per field \pm S.E.M. of three independent experiments. ${ }^{*} P<0.05$, compared to the untreated control; ${ }^{\sharp} P<0.05$, compared to the VEGF-treated group.

DPI $(10 \mu \mathrm{M})$ or PD98059 $(10 \mu \mathrm{M})$ (Fig. 5C and 5D). In a similar manner, TROG inhibited VEGF-induced MMP-2 protein secretion measured by ELISA (Fig. 5E) and MMP-2 activity revealed in the zymogram assay (Fig. 5F). In contrast to MMP-2, MMP-9 activity was very weak, and not affected by VEGF and TROG.

\section{TROG inhibits angiogenesis in vivo}

To verify the anti-angiogenic activity of TROG in vivo, we performed a CAM assay. TROG alone had no effect on neovascularization on chick embryo CAM (Fig. 6). However, VEGF (20 ng/ml)-stimulated blood vessel formation was significantly suppressed by treatment of CAM with TROG $(0.05,0.1$, and $0.2 \mu \mathrm{g} / \mathrm{CAM})$ in a dose-dependent manner. The inhibitory effect of 
A

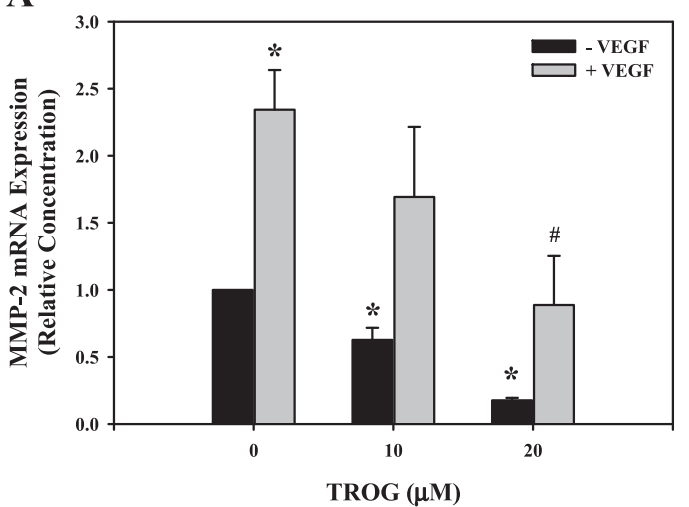

C

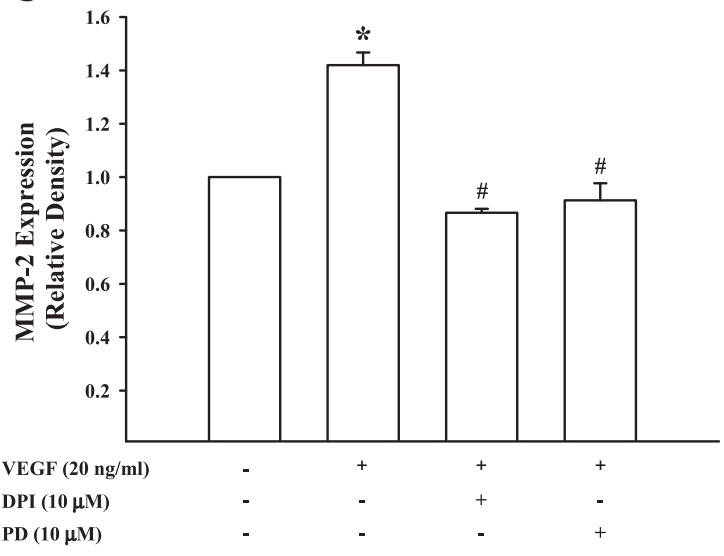

B

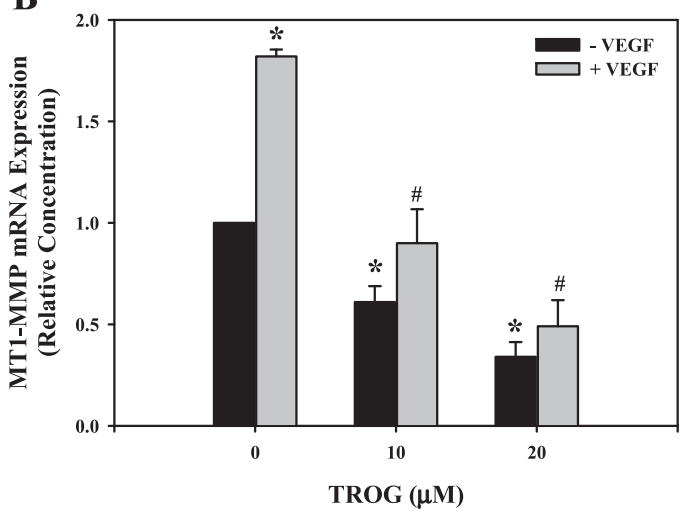

D

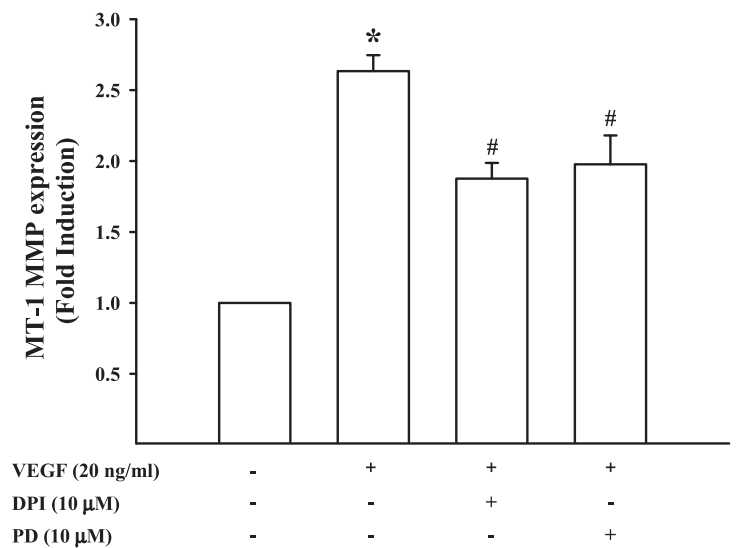

$\mathbf{E}$

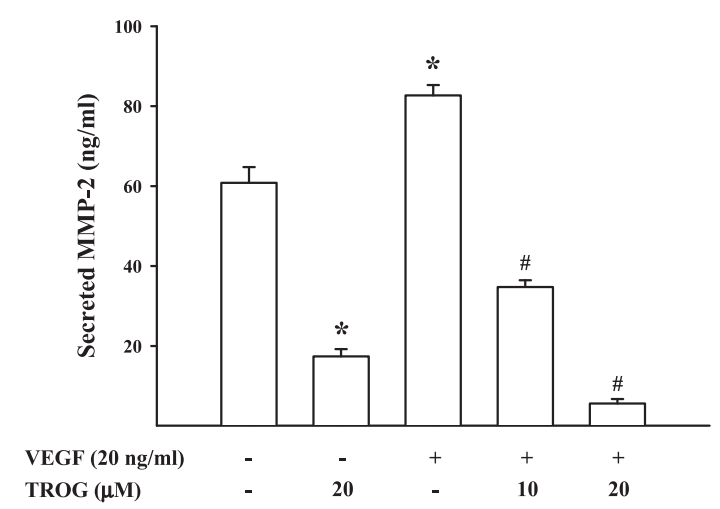

F VEGF

TROG $(\mu \mathrm{M})$

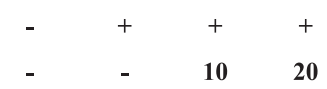

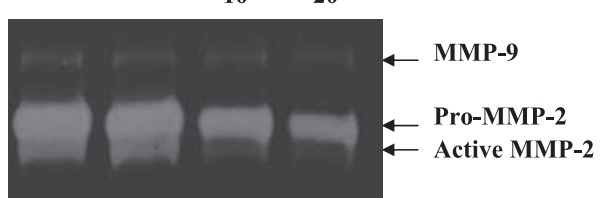

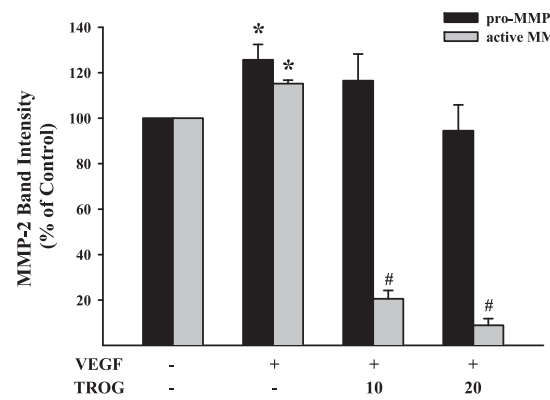

Fig. 5. TROG inhibits VEGF-induced MMP-2 and MT1-MMP expression in HUVECs. A and B: Quantitative real-time PCR for MMP-2 (A) and MT1-MMP (B) mRNA expression was performed using the SYBR Green PCR kit (Qiagen). The data represent the mean of three different sets of experiments conducted in triplicate. The black and gray colors in the bar graphs represent the HUVECs treated with TROG in the absence or presence of VEGF, respectively. C and D: HUVECs were treated with DPI or PD98059 for $24 \mathrm{~h}$ in the presence of VEGF (20 ng/ml). Quantitative real-time PCR for MMP-2 (C) and MT1-MMP (D) mRNA expression was performed as described in A and B. E and F: HUVECs were co-treated with VEGF and TROG for $24 \mathrm{~h}$. The secreted amount of MMP-2 (E) in the conditioned media was measured by using ELISA and normalized by the total number of viable cells determined by an MTT method. The conditioned media were also analyzed for gelatinolytic activity of MMP-2 by zymography (F). The black and gray bar graphs under the zymogram represent the relative band intensity of proMMP-2 and active MMP-2, respectively. ${ }^{*} P<0.05$, compared to the vehicle-treated control group; ${ }^{\sharp} P<0.05$, compared to the VEGF-treated group. 

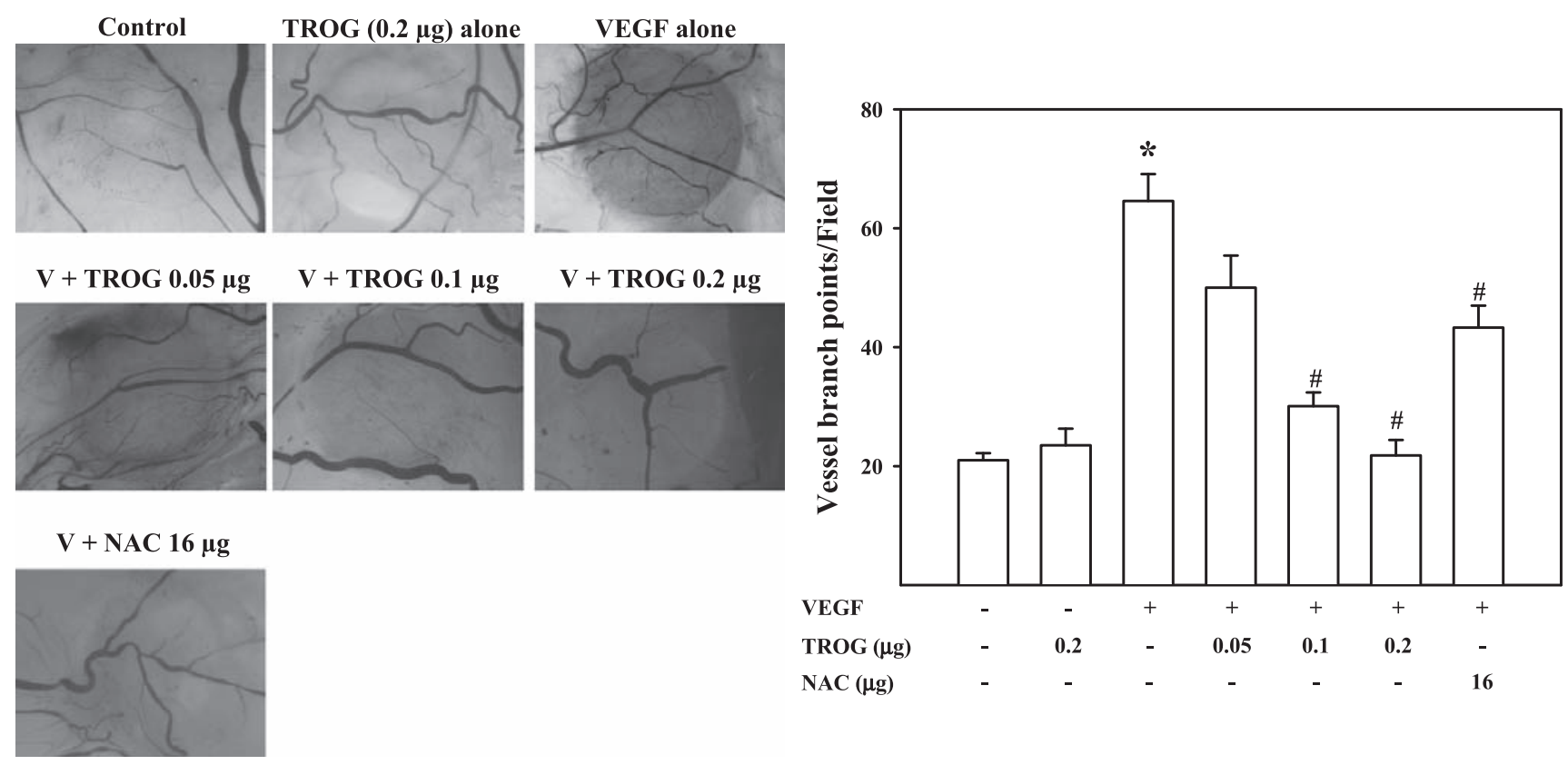

Fig. 6. TROG inhibits VEGF-induced angiogenesis in CAM assay. VEGF $(20 \mathrm{ng} / \mathrm{ml})$ or vehicle $(0.1 \%$ bovine serum albumin in PBS) was placed on the CAM of a 10-day-old chick embryo. TROG and NAC were introduced 30 min later on top of the CAMs by means of the filter disks. After 3 days of incubation, digital images (magnification: $\times 50$ ) of CAM sections exposed to filters were captured as representative images and imported into the image analysis program to quantify the number of new vessel branches formed. V represents VEGF. The bar graphs each represent the mean \pm S.E.M. of at least six chick embryos. ${ }^{*} P<0.05$, compared to the vehicle-treated control group; ${ }^{\#} P<0.05$, compared to the VEGF-treated group.

TROG was more obvious than that of NAC, an antioxidant (Fig. 6).

\section{Discussion}

Accumulating evidence has contributed toward elucidating the versatile role of PPAR $\gamma$ in modulating diverse biological functions such as lipid biosynthesis and glucose metabolism, as well as cell fate determination $(1-3,26,27)$. Furthermore, since various PPAR $\gamma$ ligands inhibited growth and migration of vascular endothelial cells, smooth muscle cells, monocytes, and certain tumor cells $(28-30), \operatorname{PPAR} \gamma$ has been recognized as a potential therapeutic target for the treatment of pathological neovascularization $(31,32)$. There are several lines of in vitro and in vivo evidence to support the postulation that a PPAR $\gamma$ ligand can also induce tumor angiogenesis $(33-36)$ through an indirect action on endothelial cells by inducing the expression of the proangiogenic factor VEGF or PPAR $\gamma$ coactivator (PGC)- $1 \alpha$ in cancer cells. However, the apoptosisinducing ability of PPAR $\gamma$ activators in malignant transformed cells $(37-39)$ may surpass the reality of the pro-angiogenic factor expression in tumor tissues. Furthermore, recent investigations supported the importance of endothelial cells among many cell types in relation to PPAR $\gamma$-mediated anti-angiogenic therapy because endothelial cells express functionally active $\operatorname{PPAR} \gamma(30,40,41) .15 \mathrm{~d}-\mathrm{PGJ} 2$, an endogenous PPAR $\gamma$ ligand, and thiazolidinediones, the best known exogenous $\operatorname{PPAR} \gamma$ ligands, inhibit endothelial proliferation and differentiation into tube-like structures $(31,42)$. Rosiglitazone directly suppressed the growth of a variety of tumors and metastatic invasion by inhibiting angiogenesis (41). In addition, TROG inhibited VEGFinduced cell proliferation, migration, and tube formation of bovine choroidal endothelial cells (31). Similarly, the present study clearly demonstrated that TROG inhibited VEGF-induced angiogenesis in both the in vivo chick CAM assay and in vitro human umbilical endothelial cell proliferation, migration and tube formation analysis.

Increasing evidence suggests that many angiogenic responses of endothelial cells are dependent on ROS generated by endothelial NADPH oxidase upon stimulation by angiogenic factors $(5,6,43,44)$. The effects of PPAR $\gamma$ agonists on cellular ROS level vary depending on the type of stimuli administered to the cell. Treatment of glioma or osteoblastic cells with ciglitazone or TROG alone increases the ROS level $(45,46)$. However, when the cells are co-treated with other agents such as $12-O$ tetradecanoylphorbol-13-acetate (TPA) and octanoate, 
all of which stimulate cellular proliferation or lipogenesis, PPAR $\gamma$ agonists suppress the agent-induced ROS generation $(47,48)$. Furthermore, in leukocytes isolated from TROG-treated obese patients, TROG was found to suppress the ROS generation $(49,50)$. The present study clearly showed that TROG inhibited VEGF-induced NADPH oxidase-mediated ROS production (Fig. 2A). The results obtained with endothelial cells correspond to reports by Jung et al. (51) showing that TROG suppressed the tumor necrosis factor (TNF)$\alpha$-stimulated NADPH oxidase 4 (NOX4)-dependent ROS generation. Moreover, our study also showed that this inhibitory effect of TROG was not suppressed by GW9662. However, the PPAR $\gamma$ antagonist GW9662 alone blocked VEGF-induced ROS production, suggesting that ligand binding of PPAR $\gamma$ may possibly induce direct inhibition of the VEGF-induced activation of NADPH oxidase.

Similar to the VEGF-induced HUVEC proliferation, ROS are reported to be involved in the activation and expression of pro-MMP-2 in vascular cells (15). Our results showed that the inhibitory effect of TROG on the VEGF-induced MMP-2 and MT1-MMP expression was similar to that of DPI treatment, an NADPH oxidase inhibitor. In addition, our results showed that TROG suppressed the VEGF-induced ERK phosphorylation and that MMP-2 and MT1-MMP expression was also inhibited by PD98059. Furthermore, PD98059 did not suppress the VEGF-induced ROS production, and DPI inhibited ERK phosphorylation, indicating that ROS are the upstream signal for the activation of ERK. These results suggest that the inhibitory effect of TROG on VEGF-induced MMP expression is mediated through the suppression of NADPH oxidase-generated ROS and ERK signaling.

TROG alone significantly suppressed the expression of MMP-2 and MT1-MMP in HUVECs. Nevertheless, TROG did not inhibit in vitro tube formation (Fig. 4A) and Matrigel invasion (Fig. 4C) of HUVECs and in vivo neovascularization as determined by the CAM assay (Fig. 6). These results suggest that down regulation of MMP-2 and MT1-MMP mRNA level is not enough for TROG action in the inhibition of angiogenesis, and other factors required for blood vessel formation may not be inhibited by TROG. One possible factor is tissue inhibitors of metalloproteinase (TIMP)-2. In the activation of MMP-2, TIMP-2 plays a dual role (52). Low levels of TIMP-2 are related to MT1-MMPmediated activation of MMP-2, but high TIMP-2 levels directly inhibit MT1-MMP-mediated MMP-2 activation. In addition, MMP-1 and MMP-10, which are known to be involved in regression of human capillary tubular structures (53), may be other possible factors. Future studies about the effect of TROG on these molecules are still needed.

The present study also showed that the concentration of TROG inducing anti-angiogenic activity was higher than that for receptor activation. These results are comparable to the previous report showing that high concentrations of rosiglitazone, which are greater than the concentration required for receptor activation, inhibit HUVEC proliferation (54). In addition, the PPAR $\gamma$ antagonists BADGE and GW9662 did not block the inhibitory action of TROG in the VEGF-induced angiogenic effect. Since TROG is a PPAR $\gamma$-specific agonist as well as a ligand for human pregnan $\mathrm{X}$ receptor (PXR), we can not exclude the possibility that GW9662 may not be enough to block activation of PPAR $\gamma$, PXR, or the interaction between PPAR $\gamma$ and PXR. Therefore, it can not be concluded that the antiangiogenic action of TROG was mediated through a PPAR $\gamma$-independent pathway.

In conclusion, the anti-angiogenic activity of TROG is mediated through suppression of VEGF-induced ROS production, which leads to ERK phosphorylation.

\section{Acknowledgment}

This work was supported by a Korea Research Foundation Grant (KRF-2005-204-E00119).

\section{References}

1 Cao Y, Ji RW, Davidson D, Schaller J, Marti D, Söhndel S, et al. Kringle domains of human angiostatin. Characterization of the anti-proliferative activity on endothelial cells. J Biol Chem. 1996;271:29461-29467.

2 Margeli A, Kouraklis G, Theocharis S. Peroxisome proliferator activated receptor-gamma (PPAR-gamma) ligands and angiogenesis. Angiogenesis. 2003;6:165-169.

3 Matsumoto T, Claesson-Welsh L. VEGF receptor signal transduction. Sci STKE. 2001;2001:RE21.

4 Kroll J, Waltenberger J. The vascular endothelial growth factor receptor KDR activates multiple signal transduction pathways in porcine aortic endothelial cells. J Biol Chem. 1997;272:3252132527.

5 Ushio-Fukai M, Tang Y, Fukai T, Dikalov S, Ma Y, Fujimoto $\mathrm{M}$, et al. Novel role of gp91phox-containing NAD(P)H oxidase in vascular endothelial growth factor-induced signaling and angiogenesis. Circ Res. 2002;91:1160-1167.

6 Yamaoka-Tojo M, Ushio-Fukai M, Hilenski L, Dikalov SI, Chen YE, Tojo T, et al. IQGAP1, a novel vascular endothelial growth factor receptor binding protein, is involved in reactive oxygen species-dependent endothelial migration and proliferation. Circ Res. 2004;95:276-283.

7 Chang C, Werb Z. The many faces of metalloproteases: cell growth, invasion, angiogenesis and metastasis. Trends Cell Biol. 2001;11:S37-S43.

8 Johnsen M, Lund LR, Rømer J, Almholt K, Danø K. Cancer 
invasion and tissue remodeling: common themes in proteolytic matrix degradation. Curr Opin Cell Biol. 1998;10:667-671.

9 Takino T, Miyamori H, Watanabe Y, Yoshioka K, Seiki M, Sato H. Membrane type 1 matrix metalloproteinase regulates collagen-dependent mitogen-activated protein/extracellular signal-related kinase activation and cell migration. Cancer Res. 2004;64:1044-1049.

10 Galis ZS, Sukhova GK, Lark MW, Libby P. Increased expression of matrix metalloproteinases and matrix degrading activity in vulnerable regions of human atherosclerotic plaques. J Clin Invest. 1994;94:2493-2503.

11 Mun-Bryce S, Rosenberg GA. Matrix metalloproteinases in cerebrovascular disease. J Cerebral Blood Flow Metab. 1998; 18:1163-1172.

12 Kliche S, Waltenberger J. VEGF receptor signaling and endothelial function. Iumb Life. 2001;52:61-66.

13 Itoh Y, Takamura A, Ito N, Maru Y, Sato H, Suenaga N, et al. Homophilic complex formation of MT1-MMP facilitates proMMP-2 activation on the cell surface and promotes tumor cell invasion. EMBO J. 2001;20:4782-4793.

14 Kim KH, Cho YS, Park JM, Yoon SO, Kim KW, Chung AS. Pro-MMP-2 activation by the PPARgamma agonist, ciglitazone, induces cell invasion through the generation of ROS and the activation of ERK. FEBS Lett. 2007;581:3303-3310.

15 Grote K, Flach I, Luchtefeld M, Akin E, Holland SM, Drexler $\mathrm{H}$, et al. Mechanical stretch enhances mRNA expression and proenzyme release of matrix metalloproteinase-2 (MMP-2) via $\mathrm{NAD}(\mathrm{P}) \mathrm{H}$ oxidase-derived reactive oxygen species. Circ Res. 2003;92:80-86.

16 Takada I, Suzawa M, Kato S. Nuclear receptors as targets for drug development: crosstalk between peroxisome proliferatoractivated receptor $\gamma$ and cytokines in bone marrow-derived mesenchymal stem cells. J Pharmacol Sci. 2005;97:184-189.

17 Gralinski MR, Rowse PE, Breider MA. Effects of troglitazone and pioglitazone on cytokine-mediated endothelial cell proliferation in vitro. J Cardiovasc Pharmacol. 1998;31: 909-913.

18 Goetze S, Bungenstock A, Czupalla C, Eilers F, Stawowy P, Kintscher $U$, et al. Leptin induces endothelial cell migration through Akt, which is inhibited by PPARgamma-ligands. Hypertension. 2002;40:748-754.

19 Liu J, Lu H, Huang R, Lin D, Wu X, Lin Q, et al. Peroxisome proliferator activated receptor-gamma ligands induced cell growth inhibition and its influence on matrix metalloproteinase activity in human myeloid leukemia cells. Cancer Chemother Pharmacol. 2005;56:400-408.

20 Marx N, Schönbeck U, Lazar MA, Libby P, Plutzky J. Peroxisome proliferator-activated receptor gamma activators inhibit gene expression and migration in human vascular smooth muscle cells. Circ Res. 1998;83:1097-1103.

21 Game BA, Xu M, Lopes-virella MF, Huang Y. Regulation of MMP-1 expression in vascular endothelial cells by insulin sensitizing thiazolidinediones. Atherosclerosis. 2003;169:235243.

22 Yoshimoto K, Nishizawa S, Koshino H, Sato Y, Teramae N, Maeda M. Assignment of hydrogen-bond structure in a ligandnucleobase complex inside duplex DNA: combined use of quantum chemical calculations and 15N NMR experiments. Nucleic Acids Symp Ser (Oxf). 2005;49:255-256.

23 Kim MS, Lee EJ, Kim HR. Moon A. p38 kinase is a key signaling molecule for H-Ras-induced cell motility and invasive phenotype in human breast epithelial cells. Cancer Res. 2003; 63:5454-5461.

24 Herron GS, Banda MJ, Clark EJ, Gavrilovic J, Werb Z. Secretion of metalloproteinases by stimulated capillary endothelial cells. II. Expression of collagenase and stromelysin activities is regulated by endogenous inhibitors. J Biol Chem. 1986;261: 2814-2818.

25 Xia Z, Dickens M, Raingeaud J, Davis RJ, Greenberg ME. Opposing effects of ERK and JNK-p38 MAP kinases on apoptosis. Science. 1995;270:1326-1331.

26 Folkman J. Angiogenesis in cancer, vascular, rheumatoid and other disease. Nat Med. 1995;1:27-31.

27 Maeyama K, Emi M, Tachibana M. Nuclear receptors as targets for drug development: peroxisome proliferator-activated receptor $\gamma$ in mast cells: its roles in proliferation and differentiation. J Pharmacol Sci.2005;97:190-194.

28 Hsueh WA, Law RE. PPARgamma and atherosclerosis: effects on cell growth and movement. Arterioscler Thromb Vasc Biol. 2001;21:1891-1895.

29 Willson TM, Lambert MH, Kliewer SA. Peroxisome proliferatoractivated receptor gamma and metabolic disease. Annu Rev Biochem. 2001;70:341-367.

30 Konturek PC, Kania J, Kukharsky V, Raithel M, Ocker M, Rembiasz $\mathrm{K}$, et al. Implication of peroxisome proliferatoractivated receptor $\gamma$ and proinflammatory cytokines in gastric carcinogenesis: link to Helicobacter pylori-infection. J Pharmacol Sci. 2004;96:134-143.

31 Xin X, Yang S, Kowalski J, Gerritsen ME. Peroxisome proliferator-activated receptor gamma ligands are potent inhibitors of angiogenesis in vitro and in vivo. J Biol Chem. 1999;274:9116-9121.

32 Murata T, Hata Y, Kim S, Hsueh WA, Law RE, Hinton DR. Response of experimental retinal neovascularization to thiazolidinediones. Arch Ophthalmol. 2001;119:709-717.

33 Jozkowicz A, Dulak J, Piatkowska E, Placha W, DembinskaKiec A. Ligands of peroxisome proliferatoractivated receptor- $\gamma$ increase the generation of vascular endothelial growth factor in vascular smooth muscle cells and inmacrophages. Acta Biochimica Polonica. 2000;47:1147-1157.

34 Yamakawa K, Hosoi M, Koyama H, Tanaka S, Fukumoto S, Morii $\mathrm{H}$, et al. Peroxisome proliferator-activated receptor- $\gamma$ agonists increase vascular endothelial growth factor expression in human vascular smooth muscle cells. Biochem Biophys Res Commun. 2000;271:571-574.

35 Chintalgattu V, Harris GS, Akula SM, Katwa LC. PPAR- $\gamma$ agonists induce the expression of VEGF and its receptors in cultured cardiac myofibroblasts. Cardiovasc Res. 2007;74:140 150.

36 Chu K, Lee ST, Koo JS, Jung KH, Kim EH, Sinn DI, et al. Peroxisome proliferatoractivated receptor- $\gamma$-agonist, rosiglitazone, promotes angiogenesis after focal cerebral ischemia. Brain Res. 2006;1093:208-218.

37 Cui Y, Lu Z, Bai L, Shi Z, Zhao WE, Zhao B. $\beta$-Carotene induces apoptosis and up-regulates peroxisome proliferatoractivated receptor $\gamma$ expression and reactive oxygen species production in MCF-7 cancer cells. Eur J Cancer. 2007;43:25902601.

38 Sun H, Berquin IM, Owens RT, O'Flaherty JT, Edwards IJ. Peroxisome proliferator-activated receptor $\beta$-mediated upregulation of syndecan-1 by $n-3$ fatty acids promotes apoptosis 
of human breast cancer cells. Cancer Res. 2008;68:2912-2919.

39 Borbath I, Leclercq I, Moulin P, Sempoux C, Horsmans Y. The PPARgamma agonist pioglitazone inhibits early neoplastic occurrence in the rat liver. Eur J Cancer. 2007;43:1755-1763.

40 Bishop-Bailey D, Hia T. Endothelial cell apoptosis induced by the peroxisome proliferator-activated receptor (PPAR) ligand 15-deoxy- $4^{12,14}$-rostaglandin $\mathrm{J}_{2}$. J Biol Chem. 1999;274:1704217048.

41 Panigrahy D, Singer S, Shen LQ, Butterfield CE, Freedman DA, Chen EJ, et al. PPAR- $\gamma$ ligands inhibit primary tumor growth and metastasis by inhibiting angiogenesis. J Clin Invest. 2002;110: 923-932.

42 Marx N, Bourcier T, Sukhova GK, Libby P, Plutzky J. PPARgamma activation in human endothelial cells increases plasminogen activator inhibitor type-1 expression: PPARgamma as a potential mediator in vascular disease. Aterioscler Thromb Vasc Biol. 1999;19:546-551.

43 Ikeda S, Ushio-Fukai M, Zuo L, Tojo T, Dikalov S, Patrushev NA, et al. Novel role of ARF6 in vascular endothelial growth factor-induced signaling and angiogenesis. Circ Res. 2005;96: 467-475.

44 Tojo T, Ushio-Fukai M, Yamaoka-Tojo M, Ikeda S, Patrushev NA, Alexander RW. Role of gp91phox (Nox2)-containing $\mathrm{NAD}(\mathrm{P}) \mathrm{H}$ oxidase in angiogenesis in response to hindlimb ischemia. Circulation. 2005;111:2347-2355.

45 Kang DW, Choi CH, Park JY, Kang SK, Kim YK. Ciglitazone induces caspase-independent apoptosis through down-regulation of XIAP and survivin in human glioma cells. Neurochem Res. 2008;33:551-561.

46 Jung JY, Yoo CI, Kim HT, Kwon CH, Park JY, Kim YK. Role of mitogen-activated protein kinase (MAPK) in troglitazoneinduced osteoblastic cell death. Toxicology. 2007;234:73-82.
47 Kim HJ, Woo IS, Kang ES, Eun SY, Kim GH, Ham SA, et al. Phorbol ester potentiates the growth inhibitory effects of troglitazone via up-regulation of PPARgamma in A549 cells. Biochem Biophys Res Commun. 2006;349:660-667.

48 Guo W, Xie W, Han J. Modulation of adipocyte lipogenesis by octanoate: involvement of reactive oxygen species. Nutr Metab (Lond). 2006;3:30.

49 Garg R, Kumbkarni Y, Aljada A, Mohanty P, Ghanim H, Hamouda $\mathrm{W}$, et al. Troglitazone reduces reactive oxygen species generation by leukocytes and lipid peroxidation and improves flow-mediated vasodilatation in obese subjects. Hypertension. 2000;36:430-435.

50 Ghanim H, Garg R, Aljada A, Mohanty P, Kumbkarni Y, Assian E, et al. Suppression of nuclear factor-kappaB and stimulation of inhibitor kappaB by troglitazone: evidence for an antiinflammatory effect and a potential antiatherosclerotic effect in the obese. J Clin Endocrinol Metab. 2001;86:1306-1312.

51 Jung JY, Yoo CI, Kim HT, Kwon CH, Park JY, Kim YK. Role of mitogen-activated protein kinase (MAPK) in troglitazoneinduced osteoblastic cell death. Toxicology. 2007;234:73-82.

52 Zucker S, Drews M, Conner C, Foda HD, DeClerck YA, Langley $\mathrm{KE}$, et al. Tissue inhibitor of metalloproteinase-2 (TIMP-2) binds to the catalytic domain of the cell surface receptor, membrane type 1-matrix metalloproteinase 1 (MT1MMP). J Biol Chem. 1998;273:1216-1222.

53 Saunders WB, Bayless KJ, Davis GE. MMP-1 activation by serine proteases and MMP-10 induces human capillary tubular network collapse and regression in 3D collagen matrices. J Cell Sci. 2005; 118:2325-2340.

54 Sheu WH, Ou HC, Chou FP, Lin TM, Yang CH. Rosiglitazone inhibits endothelial proliferation and angiogenesis. Life Sci. 2006; $78: 1520-1528$. 